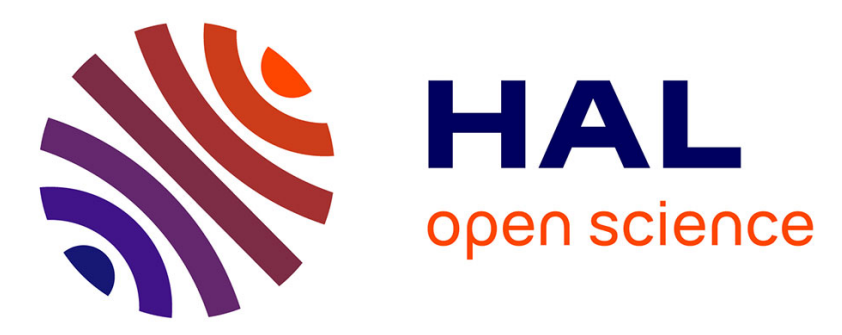

\title{
A Global Trading System in Turmoil: What is at Stake for Africa
}

\author{
Antoine Bouet, David Laborde, Fousseini Traore
}

\section{To cite this version:}

Antoine Bouet, David Laborde, Fousseini Traore. A Global Trading System in Turmoil: What is at Stake for Africa. BOUET, Antoine; ODJO, Sunday. Africa Agriculture Trade Monitor - Report 2019, International Food Policy Research Institut, p.109-131, In press, 10.2499/9780896296909_05. hal-03145878

\section{HAL Id: hal-03145878 \\ https://hal.science/hal-03145878}

Submitted on 18 Feb 2021

HAL is a multi-disciplinary open access archive for the deposit and dissemination of scientific research documents, whether they are published or not. The documents may come from teaching and research institutions in France or abroad, or from public or private research centers.
L'archive ouverte pluridisciplinaire HAL, est destinée au dépôt et à la diffusion de documents scientifiques de niveau recherche, publiés ou non, émanant des établissements d'enseignement et de recherche français ou étrangers, des laboratoires publics ou privés. 


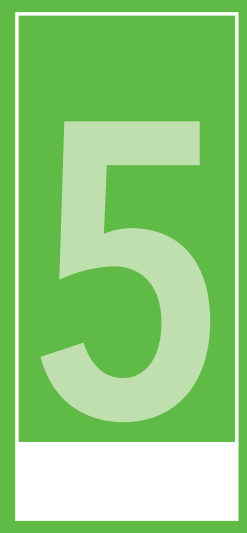

A Global Trading System in Turmoil: What is at Stake for Africa?

Antoine Bouët, Fousseini Traoré, and David Laborde 


\section{Introduction}

Over the past three years, the world trading system has been subject to profound upheavals, which some do not hesitate to describe as disruptions. First, on June 23, 2016, a majority of voters in the UK's referendum on European Union membership opted to leave the bloc. Then, on November 8,2016 , the US voted for a platform openly in favor of protectionism, promising restrictive trade policies directed towards emerging economies as well as other industrial countries.

While the UK government and the EC are still working on finalizing the modalities of separation, the new US government has moved to renegotiate the North American Free Trade Agreement, impose tariffs on a first set of imported products, and draw an indicative list of other potential products that would be subjected to tariffs should several trading partners fail to reach new agreements with the US. China reacted to the new US tariffs by imposing its own tariffs on selected US products. Both the US and China are threatening to further restrict trade between the two countries. While there has been no further move in that direction yet, it is not to be excluded that the EU and possibly Mexico or Canada may be facing new US tariffs, against which they are certain to retaliate.

Since the beginning of the new administration, the US has particularly increased its customs protection on products from China. In total, the share of US imports from China impacted by special protection increased sharply from less than 10 percent to more than 50 percent between January 2017 and December 2018 after more than 35 years of steady decline (Figure 5.1). The agricultural sector quickly came to be at the heart of the retaliation process, with China including 86 percent of US agricultural exports in the list of targeted products, compared to only 37 percent of US industrial exports. Given that the US is the largest global exporter of farm goods, the loss of its exports to China may cause ripple effects. In May 2019, the United States again increased tariffs from 10 percent to 25 percent on about 5,700 products, representing US $\$ 200$ billion of imported Chinese goods, and declared its readiness to impose additional tariffs of 25 percent on China's not previously targeted exports worth US $\$ 325$ billion. If these latter threats are implemented, as much as 100 percent of US imports from China are expected to be affected by special protection. China has again exerted trade retaliation.

The academic economic literature has looked at trade wars. From a theoretical point of view, it has been shown that, in the case of a trade war, generally all countries lose in terms of welfare, even if a large country can win a trade war against a small country (Johnson 1953). The impact of the protectionist policies initiated by the United States has often been assessed since 2017 from an empirical point of view. Bouët and Laborde (2018) use a static computable general equilibrium (CGE) model to study 18 scenarios of protectionist policies initiated by the United States against China and Mexico. Under no circumstances does the United States gain significantly in terms of welfare or gross domestic product (GDP). China's losses are systematic but limited. There may be "free riders" which benefit from the closure of American borders to Chinese products, Central America in particular. Other studies assess the effects of the same type of trade warfare, but with a focus on the United States (Amiti et al. 2019; Fajgelbaum et al. 2019). 
Figure 5.1: US imports from China covered by special protection, by sector, 1980-2018

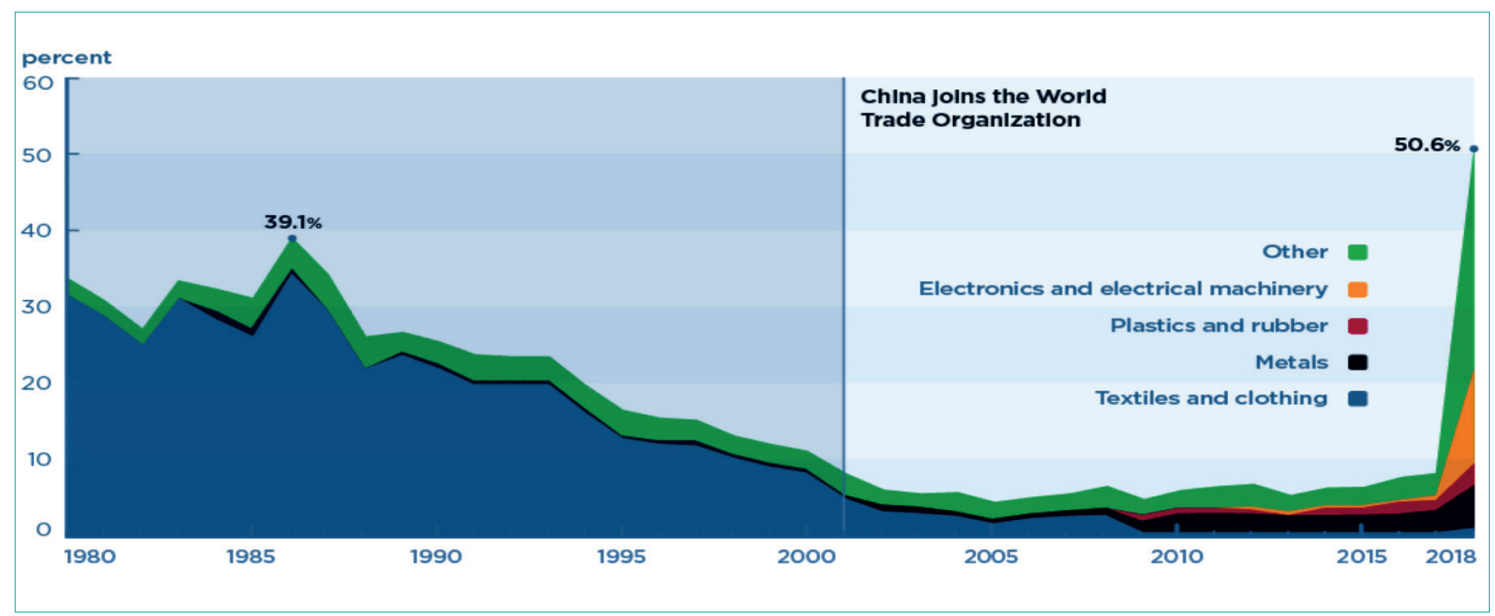

Source: Bown 2019

The trade war between the United States and China involves the two largest players in the world economy (i.e., the two countries with the largest GDPs, and the largest exporters and importers). Consequently, increasing trade tensions between these two giants are a major stake and it is expected that these tensions will negatively affect third countries through spillover effects. Trade tensions may also become even more important and may potentially concern other players in the world economy. This is why the global trading system appears to be today in turmoil.

The issue of "free riders" is interesting, as there may be collateral victims or beneficiaries of a bilateral trade war. We focus here on the potential impact of the trade war between China and the United States on African countries. To do this, given the number of countries and sectors involved, we use a dynamic multicountry and multisectoral CGE model, using a geographical disaggregation that includes a large number of African countries. We study the potential impact of the tariffs actually imposed by these two major trading partners on their respective trade flows (section 5.3). We also study the impact of trade integration on the African continent on the effects of this trade war.

Our main conclusion is that with these increasing trade tensions between the United States and China, Africa will register a net gain or a net loss in GDP and exports to these large countries depending on the intensity of the trade war. This is related to two effects, a trade diversion effect and an income effect. However, in the case of a multilateral trade war, African exports would fall significantly. Moreover, deeper integration in Africa while the world becomes more protectionist is an attractive strategy for Africa.

The chapter is structured as follows. First, we discuss the economic mechanisms that potentially could explain the impact of a trade war between China and the United States on African countries (section 5.2), in particular the income effects (impact of the trade war on the GDP of countries that could potentially import African products) and the substitution effects or trade diversion effects. We conclude that African countries can benefit from this trade war, and that this benefit is even greater if they establish a continental free trade area. 


\section{How Will Africa be Impacted?}

While the global impact of the US-China trade dispute has been much analyzed, there has been less debate about the extent to which third countries and regions could be affected (especially Africa). Yet Africa is likely to face both positive and negative outcomes from a trade war between the two giants. This section will show different impacts of these trade tensions. First, at the global level, world GDP will be negatively affected, due to lower demand for raw materials coming from Africa and lower prices. As China is a major partner for Africa, the impact could be substantial. Another potential impact is the risk of accrued competition in third markets, particularly between the US and African exporters. On the other hand, some new opportunities may emerge for African countries with new supply chain decisions by China. The overall impact on Africa of the global turmoil is, therefore, ambiguous.

\section{Global Macro Effects}

Figures 5.2 and 5.3 provide International Monetary Fund (IMF) GDP projections, illustrating the forecasts in April 2019 and the difference between those issued in March 2018 and April 2019, respectively. World GDP is projected to grow at 3.32 percent in 2019 and 3.61 percent in 2020 which, compared to 2018 projections, represents a downward revision of -0.62 and -0.15 percentage points, respectively. Although numerous factors are mentioned to explain this downward revision (macroeconomic issues in Argentina and Turkey, tighter credit and monetary policies in advanced economies, difficulties in industrial sectors of developed countries such as Germany, higher uncertainty, etc.), US-China trade tensions constitute a major consideration (IMF 2019b). For Africa south of the Sahara, growth forecasts have been revised down by -0.2 and -0.10 percentage points for 2019 and 2020, respectively. In the same vein, the World Bank's June 2019 Global Economic Prospects report (World Bank 2019) revised down global growth to 2.6 percent ( 0.3 percent below previous projections) and world trade growth for 2019 by one full percentage point: from 3.6 percent to 2.6 percent. This revision, which is larger than that of the IMF, takes into account the May 2019 increase in tariffs between the United States and China.

Figure 5.2 GDP growth projections in 2019 for 2019-2023

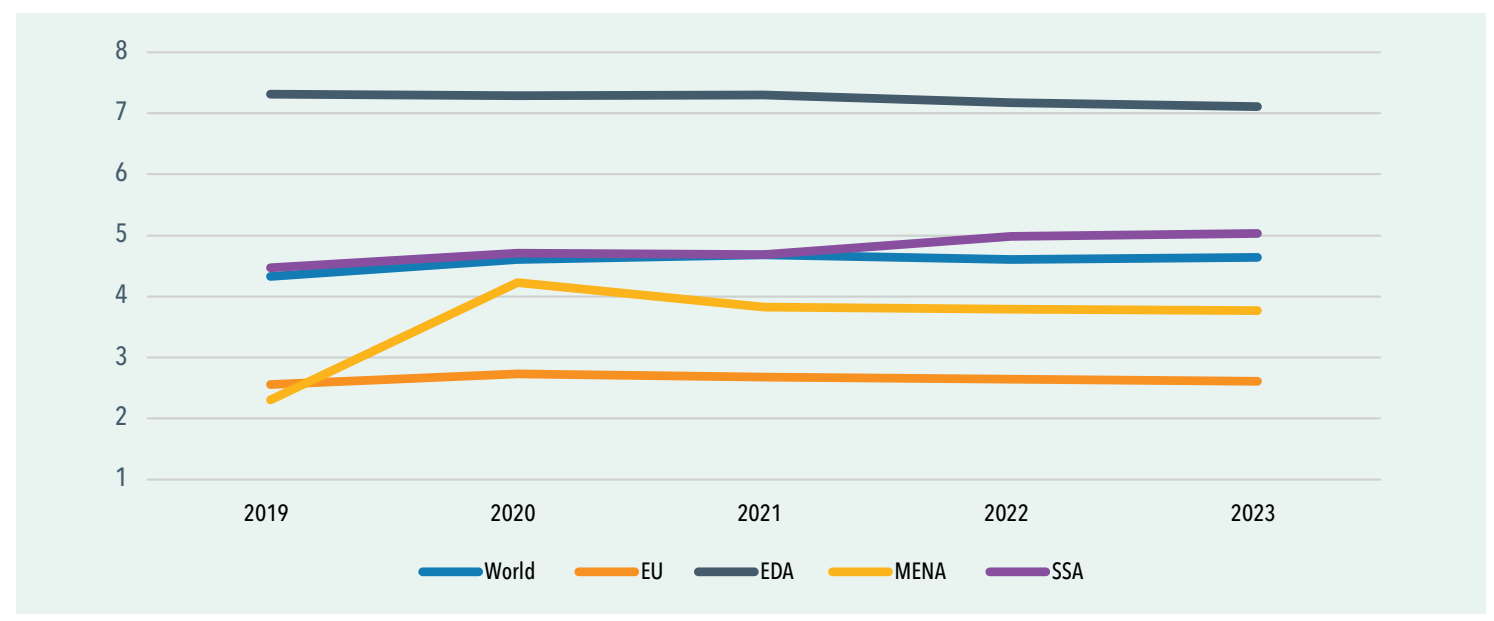

Source: IMF (2019a).

Note: MENA for Middle East and North Africa; EU for European Union; EDA for Emerging and Developing Asia; SSA for Africa, South of Sahara. 
Figure 5.3 Difference between March 2018 and March 2019 growth projections for 2019-2023

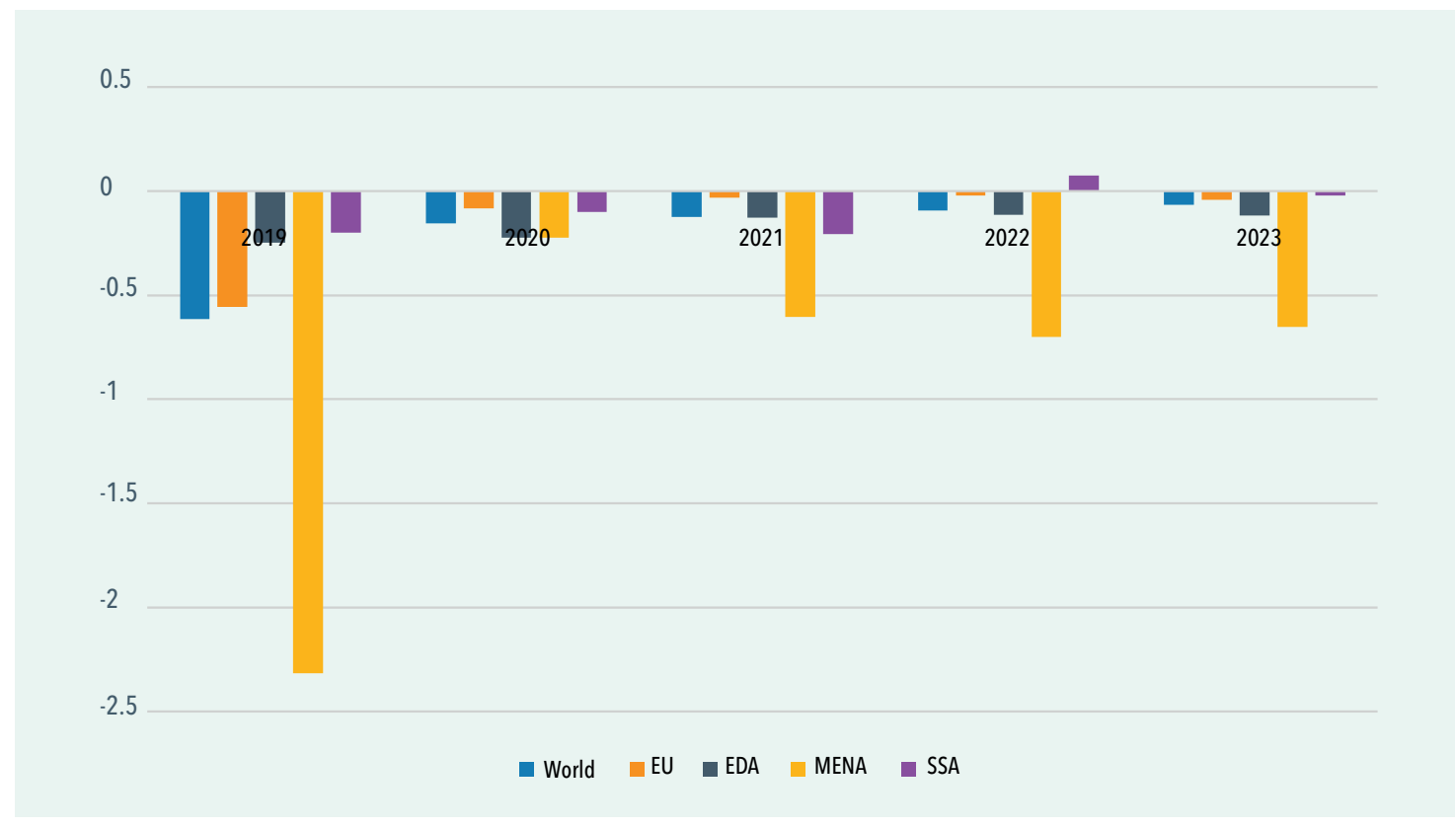

Source: IMF (2019a).

Note: MENA for Middle East and North Africa; EU for European Union; EDA for Emerging and Developing Asia; SSA for Africa, South of Sahara.

Bouët and Laborde (2018) evaluate several scenarios of trade war between the United States and China by modifying the intensity of Chinese reprisals. Total US exports are estimated to decrease between 2.7 percent to 7.7 percent in volume across the different scenarios, while total exports from Africa south of the Sahara increase slightly. Central American countries are expected to benefit most from these different trade war scenarios.

Freund et al. (2018) assess the implications of a series of tariff surcharges on products traded between China and the United States. They find that global income would decline up to 1.7 percent when combined with a decline in investor confidence (scenario with a drop in investment), with losses across all regions, while global exports fall by 3 percent. African exports could increase slightly under the full tariff war scenario but fall by 1.1 percent if the retaliation measures are accompanied by a fall in investor confidence.

In a review using three models ${ }^{1}$ to analyze a hypothetical scenario of a 25 percentage-point increase in tariffs affecting all US-China trade, the IMF (2019b) finds that world GDP would fall between -0.1 percent and -0.2 percent. While the annual real GDP losses for the United States range from -0.3 percent to -0.6 percent, and for China from -0.5 percent to -1.5 percent, the rest of the world would register a loss ranging from -0.05 percent to +0.10 percent (longrun impact; the negative effect is based on the global integrated monetary and fiscal (GIMF) model). China is estimated to be much more affected than the United States by the tariff war owing to the high US market share in total Chinese exports.

1 - The global integrated monetary and fiscal (GIMF) model, the Global Trade Analysis Project (GTAP) model, and a multisector heterogenous-firm model with entry and exit, à la Melitz' (Caliendo et al. 2017). 
With respect to trade flows, real exports for China would decrease by -3.6 percent to -5.5 percent, and United States exports would be cut by -4 percent to -6.3 percent (these ranges of variation are similar to those in Bouët and Laborde 2018). The rest of the world would benefit from increased exports to the United States at the expense of China, with real exports increasing by up to 0.4 percent. In a related study using a global vector autoregressive (VAR) model, the African Development Bank (AfDB 2019) evaluates the impact of a 1 percent contraction in world trade and concludes that the impact in the medium term (3 years) would range from -1.1 percent of GDP for non-resource-intensive exporters to -1.9 percent for oil exporters. ${ }^{2}$

The main channel through which US-China trade tensions are expected to affect African economies is through lower demand for commodities and raw materials exported by African countries, especially to China. Indeed, a decrease in Chinese exports to the United States could also result in lower exports for African countries that are large suppliers of China. In 2017, 20 percent of China's oil imports came from Africa. Figures 5.4 and 5.5 present the projected growth rate of China's trade in 2019 as well as the difference between the 2018 and 2019 forecasts. For both export and import flows there is a significant downward revision compared to 2018. Import forecasts have been revised down by 2.3 percentage points in 2019, while export projections have been reduced by 1.8 percentage points. The IMF (2019b) projects China's exports to the United States to fall by 71.3 percent in the worst case. While the rest of the world would benefit from more exports to the United States (up to 6 percent), replacing previous flows from China, exports to China would decrease (up to -2.8 percent) for all models. While the disaggregation of the results does not include Africa, it is likely that the net effect will be negative, given the closer trade relations between the continent and China compared to the United States.

Figure 5.4 Growth in the volume of China's trade in \% 2019-2023

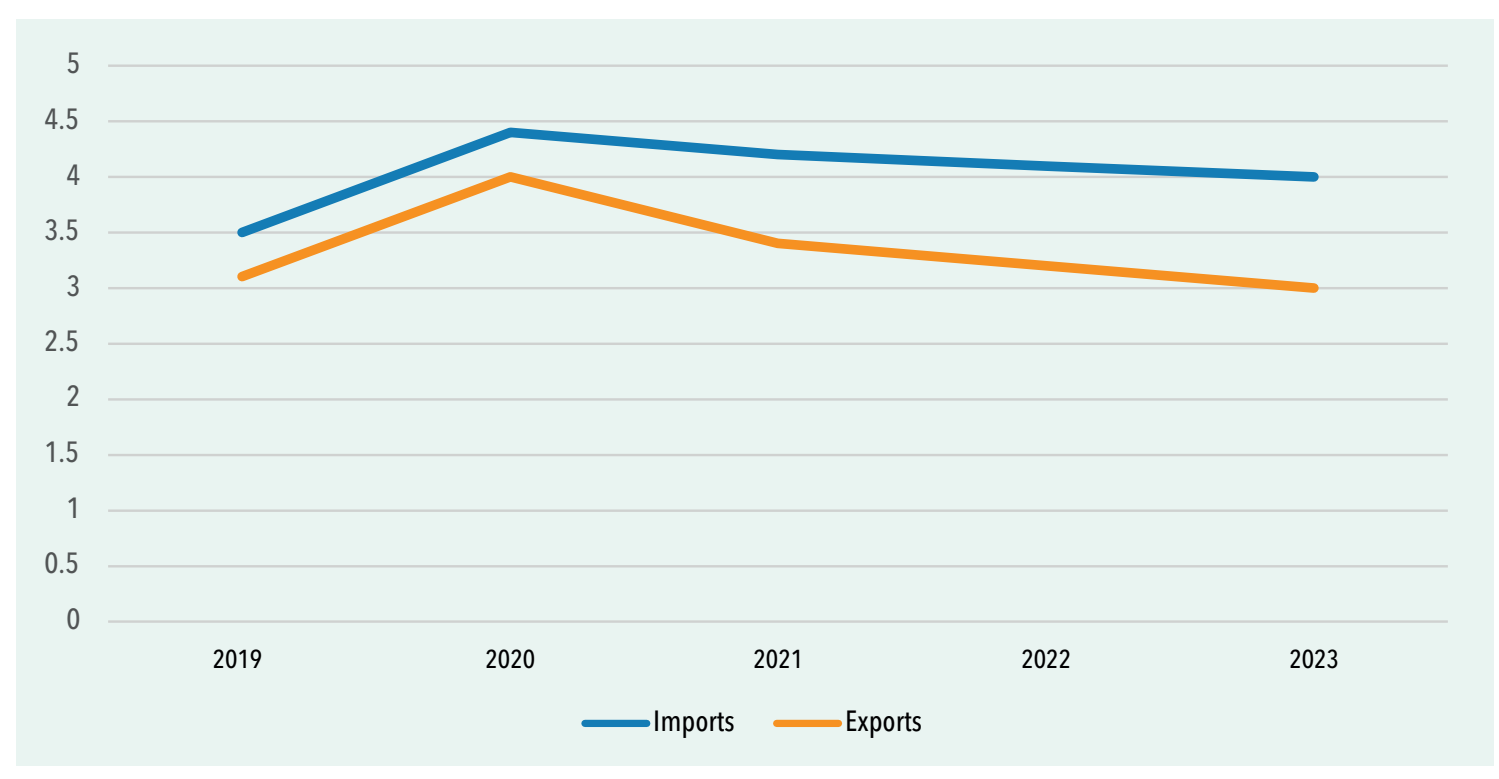

Source: IMF (2019a).

2-The results of the AfDB model should, however, be analyzed with caution. Indeed, the graphs do not explicitly indicate the confidence intervals around those estimates, and the range of variation shown tends to indicate that they are not significant. 
Figure 5.5 Changes from March 2018 projections in \%, 2019-2023

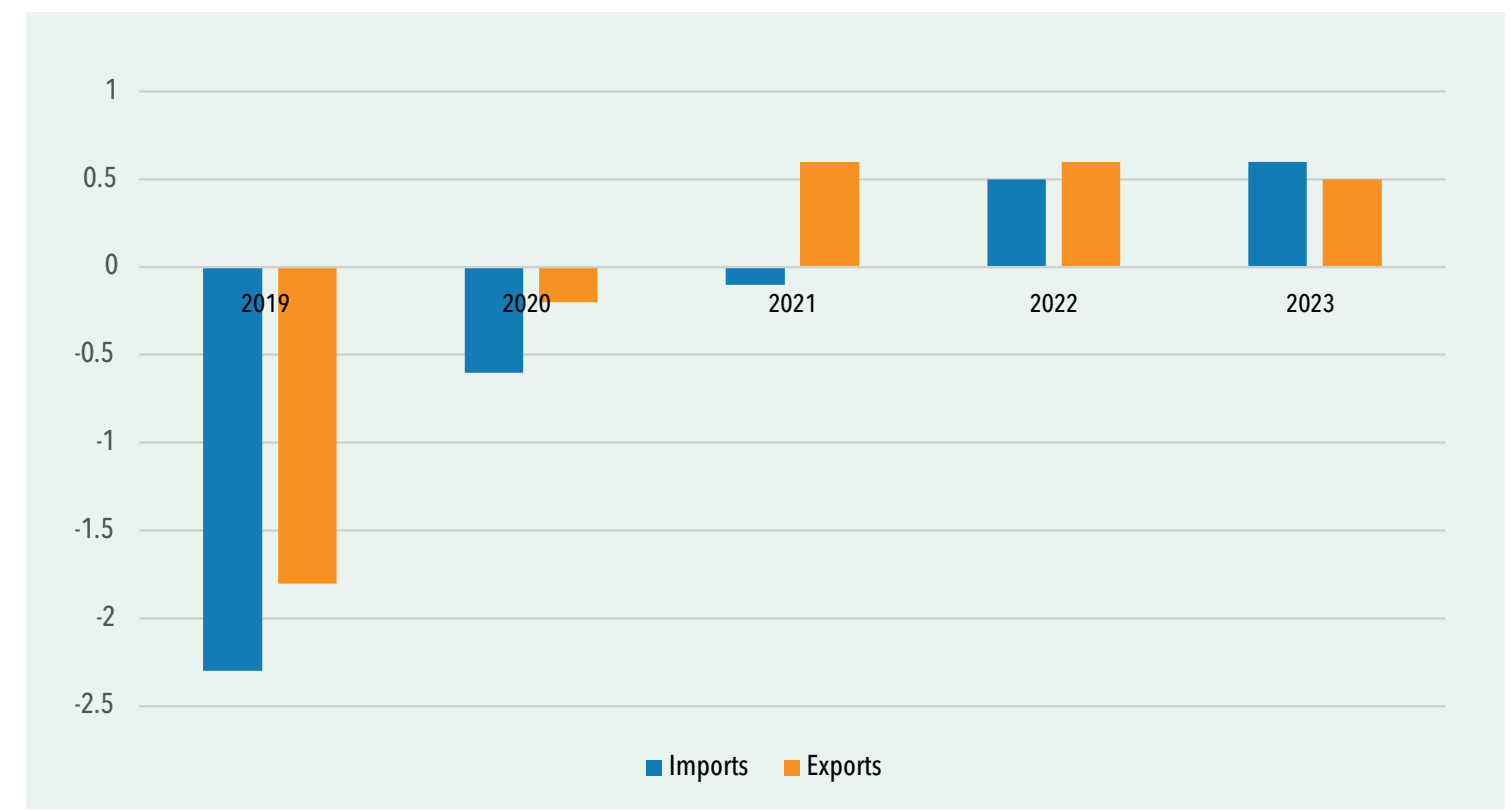

Source: IMF (2019a).

\section{Sectoral Effects and Specific Value Chains Impacted}

Subsection 5.2.1 shows that trade tensions are likely to cause global demand to contract, particularly in China, at the expense of African exporters. As demand contracts, the main consequence will be lower quantities exported by African countries to China and lower prices for the commodities under consideration. According to the IMF (2019c), more than half of the growth slowdown forecast in Africa south of the Sahara in 2019 and 2020 may be attributed to these negative terms of trade effects, the most affected countries being commodity exporters that have strong linkages with China. Figures 5.6 and 5.7 highlight the projected evolution for commodity prices in the coming years. From the 2018 peak, a decline is expected over the next 4 years. Oil and several mineral prices had already fallen in the second half of 2018. Compared to 2018 projections, recent tensions have led the IMF to project an intensification in the fall in prices for 2019 and 2020. 
Figure 5.6 Commodity Price Index $(2005=100)$ 2019-2023

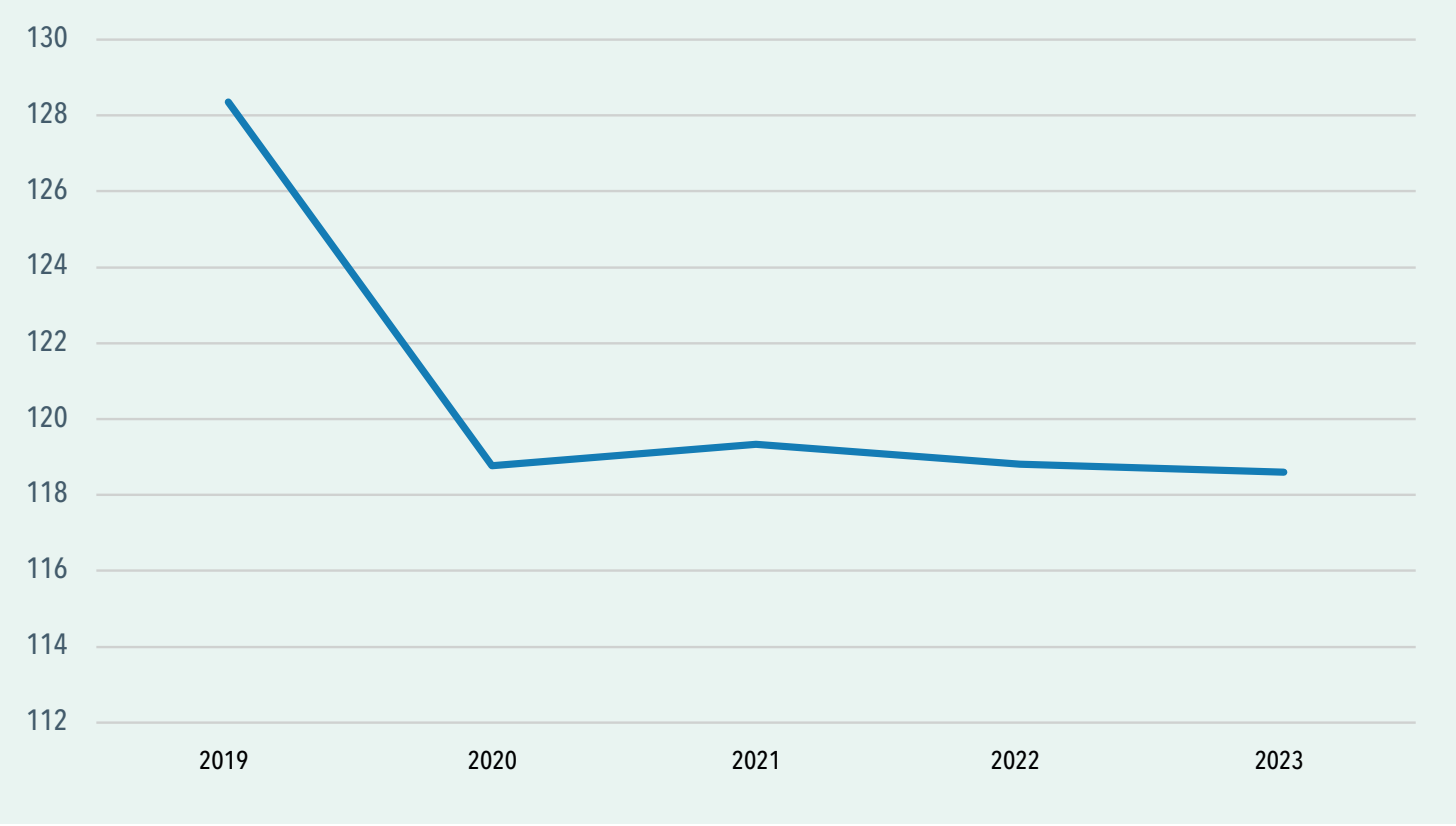

Source: IMF (2019a).

Figure 5.7 Commodity price index fuel and non-fuel price indices changes from March 2018 projections, 2019-2022

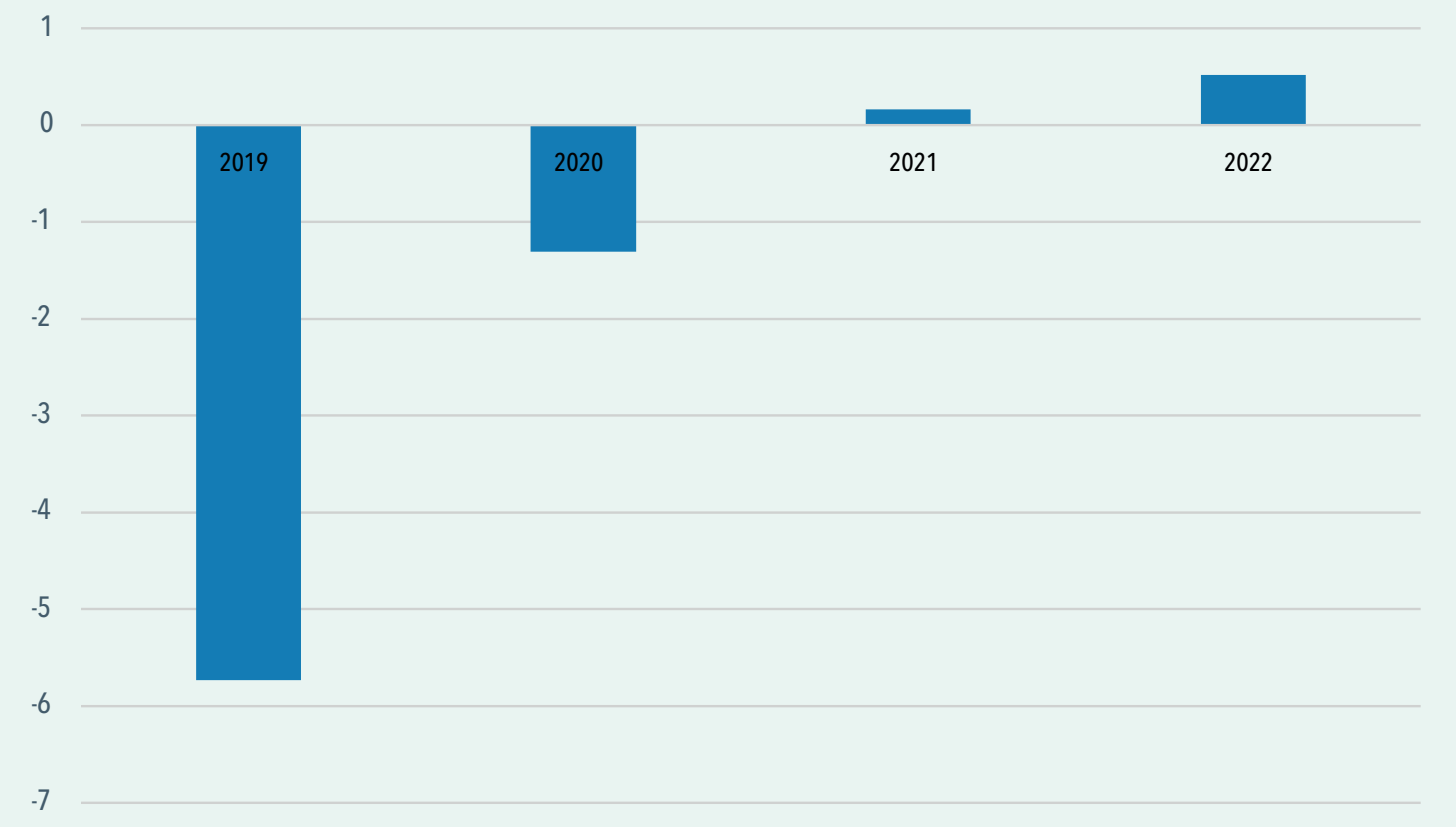

Source: IMF (2019a). 
The literature shows that contraction in Chinese production and trade will be concentrated in industrial products. Therefore, raw materials and inputs used in the industrial production process will be the most affected by the negative shock. Previous estimates showed that the elasticity of metals and fuel prices to China's industrial production ranges from 5 percent to 7 percent (IMF 2016). Since 70 percent of Africa exports to China are commodities (oil, minerals, and metals), African countries that are the main exporters of those goods would be most affected. A country such as South Sudan acquires 95 percent of its foreign revenue from oil exports to China, while 60 percent of Angola's exports consist of oil and minerals exports to China. Analysis by the IMF (2018) and AfDB (2019) shows that 21 countries $^{3}$ that are commodity exporters are likely to be impacted. The situation of those commodity exporters is vulnerable, as many of them have yet to recover from the 2015-2016 price bust.

China's direct investment into Africa is also likely to be negatively affected. Indeed, over the last two decades China has invested substantially in resource-intensive countries in Africa, especially in metals and energy. The goal followed by China with this strategy is seemingly to secure the provision of these commodities by channeling these investments back into China through exports of metals and minerals (IMF 2019c).

While we would expect the majority of African exporters to be hurt by lower demand coming from China, the protectionist measures introduced by the Trump administration could affect a few countries exporting in the US market as well. This could be the case for South Africa. The tariffs imposed by the United States on steel and aluminum could hurt South Africa's steel industry, since the United States has decided not to grant an exemption to this country. With US $\$ 375$ million worth of aluminum and US\$950 million worth of steel exports to the United States in 2017, it is estimated that thousands of jobs in the steel industry are at risk, especially since the United States turned down the offer made by South Africa to voluntarily restrict its exports to the 2017 level (Kohnert 2018). A similar outcome is expected regarding the looming threat to raise tariffs on imported vehicles, given that the United States is the second largest destination of South Africa's car exports after the United Kingdom.

\section{New Opportunities for Africa?}

The trade tensions between the United States and China could constitute new opportunities for Africa, despite the negative effects mentioned above. First, China could start importing more oil from Africa to replace imports from the United States and reduce the dependence on Middle Eastern countries. This strategy was stated by Chinese authorities and economic actors at the 2018 September Beijing Summit on China-Africa cooperation. In addition to energy, other sectors are likely to benefit from the trade dispute. In agriculture in particular, rising tariffs on US products may bring new opportunities to African exporters that could become new suppliers of China. South Africa and Egypt are potential winners from tariff war for wine and citrus, even if the main gains are secured by Australia (Kohnert 2018).

The trade war is likely to prompt new supply chain decisions in China that could have significant impacts on Africa. The case of soybeans is an interesting example of such a phenomenon. China is targeting this product with a 25 percent tariff, despite being the largest soybean importer in the world and absorbing two-thirds of US exports. Although China has started increasing its imports from Brazil, Africa could be next. This shift in supply networks has, in fact, already seemingly begun to happen, as China has started buying soybeans from Rwanda, Ethiopia,

3 - Including Zimbabwe, Guinea, Gabon, and DRC, for which more than 40 percent of exports are destined for China (Devermont and Chiang 2019). 
Uganda, and the Democratic Republic of Congo, leading to rising prices in the region. ${ }^{4}$ In addition to buying from Africa, new investment decisions with potential land acquisitions are likely to happen in the near future if African countries do not undertake appropriate reforms (Laborde and Smaller 2018). ${ }^{5}$ Another potential consequence of the tensions, especially for the soybean sector, is new reallocation of US exports to Africa. Indeed, with the tariff escalation, the United States will end up with a surplus (potentially equivalent to millions of tons) that would likely be redirected to new destinations, to avoid low domestic prices. Along with Europe, Africa is a net importer with growing demand boosted by a dynamic poultry sector. Regions with growing needs include Nigeria, Senegal, and the Southern African Development Community (SADC) region (especially South Africa), with imports coming mainly from Latin America. However, in southern Africa, a regional market exists with Zambia and Zimbabwe as suppliers for South Africa (ACET 2014). There is, therefore, a risk of increased competition (and potential dumping) as US exporters displace those within the southern Africa region as well as those in Latin America.

\section{Quantifying potential impacts}

In this section we present a quantification of the potential effects on Africa of the US-China trade war. To do this, we use a multi-country, multi-sector dynamic CGE model. This model, known as MIRAGRODEP, has already been used to carry out this type of evaluation. ${ }^{6}$ In the version we use, the model is calibrated with the GTAP10 database. ${ }^{7}$ The trade war shock is implemented in 2018 and the results are reported for the year 2020.

A multiregion, multisector dynamic computable global CGE model is an economic representation of the world with $n$ regions and $m$ sectors. This representation accounts for the economic interdependence between productive sectors and between these sectors and markets for productive factors. The model is usually solved for an equilibrium on all markets through price adjustment. Like other CGE models, MIRAGRODEP is based on an input-output framework and its theoretical structure is derived from optimizing behavior of economic agents, particularly households and firms. Walras's law holds: if there is equilibrium in all but one of the markets, equilibrium also holds in the last market.

In a global CGE model, regions respect their budget constraints, considering financial relations with the rest of the world (as in a single-country CGE model), and global savings equal global net investment. It is noteworthy that a CGE model is not designed for business cycles, in contrast with IMF outcomes, and investment does not vary with uncertainty about the future.

In MIRAGRODEP, the government is explicitly modeled. Government income consists of taxes collected on production, on factors of production, on exports, on imports, on consumption, and on households' income. From the supply side in each sector, the production function is a Leontief function ${ }^{8}$ of value-added and intermediate inputs, and the intermediate inputs function is an aggregate constant elasticity of substitution (CES) function of all goods.

4 - Prices have increased by 25 percent in the region in less than 6 months, moving from US\$520 to US\$650 per ton. We refer to metric ton throughout the chapter. (https://www.thenational.ae/business/economy/how-africa-became-collateral-damage-in-us-china-trade-war-1.849843).

5 - http://www.ifpri.org/blog/could-us-\%E2\%80\%93-china-trade-war-lead-new-wave-land-grabs.

6 - See Bouët and Laborde (2018) and Bouët et al. (2018).

7 - The GTAP 10 database is a global database containing bilateral trade information, input-output, transportation, and protection data for 141 countries and regions (Aguiar, Narayanan, McDougall 2016).

8-This means strict complementarity between value-added and intermediate inputs. 
"Value-added" is a CES function of unskilled labor, land, natural resources, and a bundle of skilled labor and capital. ${ }^{9}$

The utilization rate of productive factors is assumed to be constant. The only factor with a fixed supply over time is natural resources. Labor supply growth rates are fixed exogenously following the evolution of the active population. Land supply is endogenous, as it depends on the real remuneration of land.

Skilled labor is the only factor that is perfectly mobile. Installed capital and natural resources are sector specific. New capital is allocated among sectors according to an investment function. Unskilled labor is imperfectly mobile between agricultural and non-agricultural sectors, according to a constant elasticity of transformation (CET) function. Land is also imperfectly mobile between agricultural sectors.

Capital in a given region, whatever its origin (domestic or foreign), is assumed to be obtained by assembling intermediate inputs according to a specific combination. The capital good is the same regardless of the sector.

The demand side is modeled in each region through a representative agent whose propensity to save is constant. The rest of the national income is used to purchase final consumption. Preferences between goods are represented by a linear expenditure system (LES)-CES function. This implies that consumption has a non-unitary income elasticity. The sector sub-utility function used in MIRAGRODEP is a nesting of four CES-Armington functions ${ }^{10}$ that defines the origin of the goods. In this study, Armington elasticities are drawn from the GTAP10 database and are assumed to be the same across regions.

The model is here calibrated on a representation of the world economy with 21 regions and 31 sectors (see Appendix). The 21 regions include China and the United States, and also 9 African regions. The 31 sectors comprise 16 agricultural-food sectors, 2 primary non-agricultural sectors, 8 industrial sectors, and 5 service sectors.

The closure of the public balance is always an important assumption. Here it is assumed that an additional consumption tax is levied to compensate in each country for the loss of customs revenue so as to leave the ratio of public balance to GDP constant and public expenditure per capita constant. With respect to the external account, we assume in the simulations that the current account balance is fixed (in the model it is expressed as a percentage of global GDP). The fixed level of the current account balance is maintained through an adjustment of the real exchange rate.

\section{A Passive Africa}

First, let us present the results related to three scenarios where Africa has no reaction in terms of trade policies. We study two scenarios of trade war between China and the United States, called S1-TW1 (increases in US customs duties on Chinese products and Chinese duties on US products, observed between the 2016 US elections and April 1, 2019) and S2-TW2 (scenario S1-TW1 plus the bilateral customs duty increases declared by the two countries since April 1, 2019). The S2-TW2 scenario is, therefore, a tougher trade war between the two countries.

9 - This specification allows us to have a different elasticity of substitution between capital and skilled labor compared to capital and unskilled labor. 10 - The Armington (1969) assumptions state that imported products and domestic products are imperfect substitutes. 
We also study an additional scenario that may illustrate a multilateral trade war: all countries adopt their best response (i.e., the tariff that maximizes their welfare). It is, therefore, a Nash equilibrium, ${ }^{11}$ and we term it the S3-Nash scenario.

Table 5.1 presents the impacts of the different scenarios on the real income of the representative household from different regions: Africa as a whole, Africa south of the Sahara, six African regional economic communities, ${ }^{12}$ the world as a whole, the group of developed economies, and the group of developing economies. Table 5.2 shows the impact of the same scenarios on the GDP of the same regions. Both tables also include a scenario (S4-AfCFTA) that will be discussed in section 5.3.2.

Table 5.1 Impact of scenarios on real household income (millions USD), 2020

\begin{tabular}{lrrrr} 
Region & S1-TW1 & S2-TW2 & S3-Nash & S4-AfCFTA \\
Africa & 438.3 & $1,258.0$ & $-8,220.2$ & $3,677.7$ \\
\hline Africa south of Sahara & 346.2 & 927.7 & $-6,606.5$ & $2,629.0$ \\
\hline AMU & 92.1 & 330.3 & $-1,613.7$ & $1,048.7$ \\
\hline ECOWAS & 96.6 & 319.4 & 438.6 & 585.3 \\
\hline SADC & 57.8 & 118.7 & $-1,281.3$ & 102.2 \\
\hline COMESA & 205.6 & 524.7 & $-3,357.5$ & $1,030.9$ \\
\hline SACU & 51.8 & 200.6 & $-3,956.4$ & $1,465.3$ \\
\hline ECCAS & 15.0 & 46.4 & 189.3 & -61.7 \\
\hline World & $-7,716.3$ & $-32,880.6$ & $-454,601.2$ & $-30,599.2$ \\
\hline Developed & $3,008.5$ & $-15,967.8$ & $-258,735.3$ & $-16,236.1$ \\
\hline Developing w/o Africa & $-11,163.1$ & $-18,170.8$ & $-187,645.7$ & $-18,040.7$ \\
\hline
\end{tabular}

Source: Authors' calculations from simulations.

Note: S1-TW1 is a trade war scenario with changes in tariffs observed from January 1, 2018 to April 1, 2019; S2-TW2 is scenario S1-TW1 plus the bilateral customs duty increases declared after April 1, 2019; S3-Nash is a scenario where all countries adopt welfare-maximizing tariffs; S4-AfCFTA is the S1-TW1 trade war scenario, plus a continental free trade area. $\mathrm{AMU}=$ Arab Maghreb Union, ECOWAS = Economic Community of Western African States, SADC = Southern African Development Community, COMESA = Common Market for Eastern and Southern Africa, SACU = Southern Africa Custom Union, ECCAS = Economic Community for Central African States.

The trade war is costly for the entire world: in particular, the increases announced after April 1,2019 , multiply by more than 4 times the loss of real income worldwide, from US\$7.7 billion (S1-TW1) to US\$32.9 billion (S2-TW2). If the trade war becomes multilateral (S3-Nash), real income losses at the global level become massive, multiplying by 59 times as compared to S1-TW1, for a total loss of US $\$ 454.6$ billion.

But these losses are concentrated in developed and non-African developing countries. All African regions benefit from a bilateral trade war whether or not the most recent tariff increases are applied. These gains are both in terms of real income of the representative household (Table 5.1) and GDP (Table 5.2). The gains are particularly strong for the southern African region (SADC and SACU): in relative terms these are the regions with the largest gains.

11 - In game theory a Nash equilibrium is a situation such that each player's strategy maximizes his payoff, given that the strategy of others is held fixed. The strategy at that point of each player is optimal against those of the other players.

12 - These various RECs overlap. This explains why the sum of the real incomes gains of the six RECs is not equal to the gain for Africa. 
Table 5.2 Impact of scenarios on gross domestic products (\%), 2020

\begin{tabular}{lrrrr} 
Region & S1-TW1 & S2-TW2 & S3-NASH & S4-AFCFTA \\
Africa & 0.01 & 0.03 & -0.50 & 0.03 \\
\hline Africa south of Sahara & 0.02 & 0.04 & -0.43 & 0.03 \\
\hline AMU & 0.01 & 0.02 & -0.67 & 0.02 \\
\hline ECOWAS & 0.01 & 0.03 & -0.11 & 0.03 \\
\hline SADC & 0.02 & 0.05 & -0.28 & 0.04 \\
\hline COMESA & 0.01 & 0.03 & -0.68 & 0.03 \\
\hline SACU & 0.01 & 0.04 & -0.99 & 0.04 \\
\hline ECCAS & 0.01 & 0.02 & -0.04 & 0.02 \\
\hline World & -0.03 & -0.09 & -1.02 & -0.09 \\
\hline Developed & -0.02 & -0.10 & -0.88 & -0.10 \\
\hline Developing w/0 Africa & -0.04 & -0.08 & -1.32 & -0.08 \\
\hline
\end{tabular}

Source: Authors' calculations from simulations.

Note: S1-TW1 is a trade war scenario with changes in tariffs observed from January 2019 to April 1, 2019; S2-TW2 is scenario S1-TW1 plus the bilateral customs duty increases declared after April 1, 2019; S3-Nash is a scenario where all countries adopt welfare-maximizing tariffs; S4-AfCFTA is the S1-TW1 trade war scenario, plus a continental free trade area. $\mathrm{AMU}=$ Arab Maghreb Union, ECOWAS = Economic Community of Western African States, SADC = Southern African Development Community, COMESA = Common Market for Eastern and Southern Africa, SACU = Southern Africa Customs Union, ECCAS = Economic Community for Central African States. ${ }^{13}$

Nevertheless, a multilateral trade war (scenario S3-Nash) is costly for everyone, including Africa, with major impacts on global markets. In this scenario, the loss of GDP is 1.02 percent worldwide with low losses for the ECCAS and ECOWAS communities, but high for AMU, COMESA, and SACU.

In contrast, a bilateral trade war can open up export opportunities for Africans, who benefit as trade flows are diverted and their own exports increase, with a knock-on effect on the economy. In scenario S2-TW2, while world exports fall in value by 1.2 percent, African exports increase by 0.4 percent, with a positive figure for each of the six regions. For Africans, the increase in crop exports is particularly strong (+0.9 percent), while world exports of the same type of goods fall by 1.5 percent and those of developed countries by 2.8 percent.

Table 5.2 shows the impact of scenarios S1-TW1 and S2-TW2 on bilateral trade in value terms. We indicate here only the most important flows for Africa, or only those with significant variations.

In section 5.2 we mention a potential negative effect of trade wars on African exports due to the slowdown in economic activity (particularly in China) which would reduce African exports of primary energy goods and minerals, but also have a potential positive effect, through trade diversion: African exports to China could substitute for US exports in some sectors.

The assessment made with the MIRAGRODEP model confirms the negative effect of trade wars between the United States and China on African exports of primary energy goods and minerals, which fall by 0.1 percent and 0.5 percent, respectively, in scenario S2-TW2.

13 - These various RECs overlap. This explains why the sum of the real incomes gains of the 6 RECs is not equal to the gain for Africa. 
But it also confirms a positive effect through trade diversion. Scenarios S1-TW1 and S2TW2 substantially alter trade between the United States and China. In scenario S1-TW1 and scenario S2-TW2, developed countries' exports to China fall by 6.5 percent and 13.2 percent, respectively, mainly due to the sharp decline in US exports ( -35.1 percent and -64.4 percent, respectively), while exports from developing countries outside Africa to the United States fall by 12.0 percent and 23.5 percent, respectively, mainly due to the fall in China's exports $(-37.0$ percent and -80.1 percent, respectively). Under these circumstances, it is understandable that opportunities are opening up for other regions of the world in terms of exports to the two largest importing countries of goods in the world. All African regions are taking advantage of this opportunity to increase their exports to these two destinations: in scenario S1-TW1 and scenario S2-TW2, in total, African exports increase by 1.4 percent (respectively 2.6 percent) to China and by 0.4 percent (respectively 2.2 percent) to the United States. Exports to China from developing countries outside Africa, however, are increasing more than those of African countries (1.7 percent and 3.5 percent, respectively). Many developing countries, particularly Asian developing countries outside China, are increasing their exports to the United States by more than African countries. Exports to China are increasingly mainly from the ECOWAS and COMESA regions, while the AMU, COMESA, and SADC regions benefit from the most significant growth in exports to the United States. The sectors with the highest export growth are agriculture and agri-food.

Table 5.3 Impact of scenarios S1-TW1 and S2-TW2 on bilateral exports (\%)-Value, 2020

\begin{tabular}{|c|c|c|c|c|c|c|}
\hline \multirow{3}{*}{ Exporter } & \multicolumn{3}{|c|}{ S1-TW1 } & \multicolumn{3}{|c|}{ S2-TW2 } \\
\hline & \multicolumn{3}{|c|}{ Importer } & \multicolumn{3}{|c|}{ Importer } \\
\hline & Africa & China & USA & Africa & China & USA \\
\hline Africa & -0.1 & 1.4 & 0.4 & -0.3 & 2.6 & 2.2 \\
\hline Africa south of Sahara & -0.1 & 1.4 & 0.0 & -0.3 & 2.5 & 1.3 \\
\hline AMU & 0.0 & 1.2 & 1.2 & -0.1 & 2.6 & 4.8 \\
\hline ECOWAS & -0.1 & 2.3 & 0.0 & -0.2 & 3.0 & 0.4 \\
\hline SADC & -0.2 & 1.4 & 0.1 & -0.4 & 2.7 & 3.5 \\
\hline COMESA & -0.1 & 1.9 & 1.3 & -0.4 & 3.2 & 6.5 \\
\hline SACU & -0.1 & 1.4 & -0.5 & -0.4 & 2.7 & 2.3 \\
\hline ECCAS & 0.0 & 1.1 & 0.2 & -0.1 & 2.2 & 0.7 \\
\hline World & 0.1 & -3.1 & -4.1 & 0.4 & -6.3 & -7.3 \\
\hline Developed & -0.1 & -6.5 & 1.5 & 0.1 & -13.2 & 4.2 \\
\hline Developing w/o Africa & 0.5 & 1.7 & -12.0 & 0.9 & 3.5 & -23.5 \\
\hline
\end{tabular}

Source: Authors' calculations from simulations.

Note: S1-TW1 is a trade war scenario with changes in tariffs observed from January 2019 to April 1, 2019; S2-TW2 is scenario S1-TW1 plus the bilateral customs duty increases declared after April 1, 2019. AMU = Arab Maghreb Union, ECOWAS = Economic Community of Western African States, SADC = Southern African Development Community, COMESA = Common Market for Eastern and Southern Africa, SACU = Southern Africa Customs Union, ECCAS = Economic Community for Central African States. ${ }^{14}$

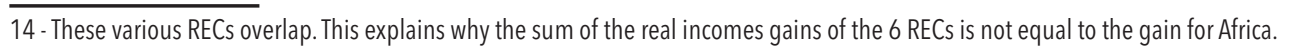


A bilateral trade war, such as that represented by either the S1-TW1 or S2-TW2 scenario, can therefore represent an opportunity for African agriculture. Table 5.4 shows the effects of scenario S2-TW2 on real value-added in agriculture in the different African regions. This trade war opens up opportunities for African farmers in most of these sectors and in most regions of Africa. This is particularly true for the oilseed sector and the SADC region, which increases its value-added in volume by 1.6 percent in this scenario. It is useful to recall that, in 2017, the United States was the largest exporter of soybeans and China the largest importer (see section 5.2.3). This highlights the potential windfall effect that Chinese retaliation on this product represents for producers in the rest of the world.

Table 5.4 Impact of scenario S2-TW2 on agricultural value-added in volume (\%), 2020

\begin{tabular}{|l|c|c|c|c|c|c|c|}
\hline Region & Rice & Wheat & Corn & $\begin{array}{c}\text { Veg. \& } \\
\text { Fruits }\end{array}$ & Oil seeds & Sugar & Fibers \\
\hline Africa & 0 & 0 & 0 & 0.1 & 0.3 & 0.2 & 0.4 \\
\hline Africa SoS & 0 & 0 & 0.1 & 0.1 & 0.6 & 0.2 & 0.6 \\
\hline AMU & 0 & 0 & -0.1 & 0.1 & -1.3 & 0.1 & 0.3 \\
\hline ECOWAS & 0 & -0.1 & 0 & 0.1 & 0.2 & 0.1 & 0.5 \\
\hline SADC & 0 & 0.3 & 0.2 & 0.1 & 1.6 & 0.2 & 0.4 \\
\hline COMESA & 0 & 0 & 0 & 0 & 0.5 & 0.1 & 0.3 \\
\hline SACU & 0.2 & 0.3 & 0.1 & 0.2 & -0.2 & 0.3 & 0.1 \\
\hline ECCAS & 0 & 0.2 & 0.1 & 0.1 & 0 & 0.1 & 2 \\
\hline
\end{tabular}

Table 5.4 (continue) Impact of scenario S2-TW2 on agricultural value-added in volume (\%), 2020

\begin{tabular}{|l|c|c|c|c|c|c|}
\hline & Other crops & Red Meat & White Meat & Dairy & Veg. Oils & Proc. Food \\
\hline Africa & 0.2 & 0.1 & 0.2 & 0.1 & 0 & 0.2 \\
\hline Africa SoS & 0.2 & 0.1 & 0.2 & 0.2 & -0.1 & 0.2 \\
\hline AMU & 0.1 & 0.1 & 0.1 & 0 & 0.4 & 0.1 \\
\hline ECOWAS & 0.2 & 0.1 & 0.1 & 0.1 & -0.1 & 0.2 \\
\hline SADC & 0.3 & 0.1 & 0.3 & 0.2 & 0 & 0.5 \\
\hline COMESA & 0.2 & 0.1 & 0.2 & 0.1 & 0.1 & 0.2 \\
\hline SACU & 0.9 & 0.2 & 0.3 & 0.1 & 0.2 & 0.2 \\
\hline ECCAS & 0.3 & 0.1 & 0.1 & $0.1>$ & 0.2 & 0.1 \\
\hline
\end{tabular}

Source: Authors' calculations from simulations.

Note: S1-TW1 is a trade war scenario with changes in tariffs observed from January 2018 to April 1, 2019; S2-TW2 is scenario S1-TW1 plus the bilateral customs duty increases declared after April 1, 2019. Africa SoS $=$ Africa south of Sahara; Veg. \& fruits = Vegetable and fruits; Dairy = Dairy products; Veg. Oils = Vegetable oils; Proc. Food = Processed food. $A M U$ = Arab Maghreb Union, ECOWAS = Economic Community of Western African States, SADC = Southern African Development Community, COMESA = Common Market for Eastern and Southern Africa, SACU = Southern Africa Customs Union, ECCAS = Economic Community for Central African States. ${ }^{15}$

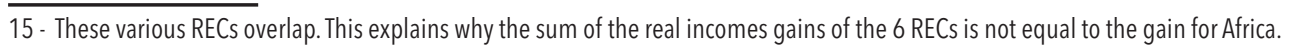


On the other hand, if the trade war becomes multilateral, the depressive effect on world GDP and on GDP in each region is so strong that the overall impact becomes negative for all countries. Not only does each country's GDP decline, which negatively affects its import demand (and the exports of its partners), but the tariffs each country imposes at its borders are also costly distortions. In the S3-Nash scenario, trade declines are particularly significant at the global level ( -27.5 percent), and even more so for developed countries ( -31.5 percent), while African countries' exports fall by only 9.9 percent.

The left side of shows the variations in bilateral merchandise trade flows between regions in scenario S3-Nash. It should be recalled that this is a multilateral trade war where each country imposes the customs duty that maximizes its welfare on the basis of the optimal tariffs of other countries or regions. Compared to the previous table, the European region (European Free Trade Association, EFTA) is added because it is an important destination in terms of trade.

Overall, Africa's total exports fall by 10.1 percent, due to a return to protectionism and a related decline in activity in all regions of the world. African exports fall by 7.4 percent to China, 15.9 percent to Europe, and 13.6 percent to the United States. On the other hand, intra-African trade increases by 14.3 percent, for two reasons. First, tariff increases are lower in Africa because African countries have lower market power, which implies lower optimal tariffs. Second, if each region sets a tariff on imports from other countries or regions, there is no change in the region's internal trade tariff. In this scenario, internal trade in ECOWAS increases by 5.4 percent, COMESA by 25.1 percent, SACU by 29.8 percent, etc.

Table 5.5 Impact of scenarios S3-Nash and S4-AfCFTA on bilateral exports (\%)-Value, 2020

\begin{tabular}{|c|c|c|c|c|c|c|c|c|}
\hline \multirow[t]{2}{*}{ Exporter } & \multicolumn{3}{|c|}{$\begin{array}{l}\text { S3-Nash } \\
\text { Importer }\end{array}$} & & \multicolumn{4}{|c|}{$\begin{array}{l}\text { S4-AfCFTA } \\
\text { Importer }\end{array}$} \\
\hline & Africa & China & EFTA & USA & Africa & China & EFTA & USA \\
\hline Africa & 14.3 & -7.4 & -15.9 & -13.6 & 34.8 & 1.5 & -1.3 & 1.1 \\
\hline Africa South of Sahara & 12.7 & -7.1 & -13.7 & -13.4 & 35.2 & 0.9 & -2.0 & -0.2 \\
\hline AMU & 26.1 & -10.5 & -18.7 & -15.8 & 30.5 & 2.6 & -0.6 & 4.4 \\
\hline ECOWAS & 3.0 & -5.6 & -7.4 & -7.7 & 82.2 & 0.6 & -2.9 & -1.4 \\
\hline SADC & 10.4 & -2.1 & -14.8 & -12.1 & 8.7 & 2.3 & -1.1 & 3.1 \\
\hline COMESA & 18.2 & -8.1 & -22.0 & -16.8 & 20.4 & 2.9 & -1.0 & 6.4 \\
\hline SACU & 19.2 & -23.7 & -28.9 & -37.3 & 17.8 & 2.5 & -0.7 & 0.9 \\
\hline ECCAS & 2.8 & 4.0 & -4.4 & -4.0 & 50.6 & -2.1 & -1.6 & -2.2 \\
\hline World & -9.9 & -37.9 & -31.7 & -43.5 & 3.1 & -6.4 & 1.6 & -7.3 \\
\hline Developed & -14.5 & -47.5 & -31.6 & -39.9 & -1.1 & -13.2 & 2.3 & 4.2 \\
\hline Developing w/o Africa & -11.1 & -26.8 & -34.7 & -50.4 & -0.6 & 3.5 & 1.6 & -23.5 \\
\hline
\end{tabular}

Source: Authors' calculations from simulations.

Note: S3-Nash is a scenario in which all countries adopt welfare-maximizing tariffs; S4-AFCFTA is the S1-TW1 trade war scenario, plus a continental free trade area. AMU = Arab Maghreb Union, ECOWAS = Economic Community of Western African States, SADC = Southern African Development Community, COMESA = Common Market for Eastern and Southern Africa, SACU = Southern Africa Customs Union, ECCAS = Economic Community for Central African States. ${ }^{16}$

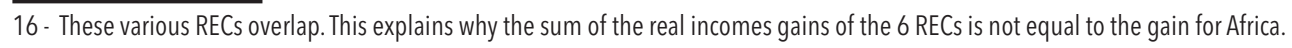




\section{A proactive strategy for Africa}

What happens if African countries have a proactive strategy and decide to set up a continental free trade area? We study here these potential consequences in a scenario where this agreement is in addition to scenario S1-TW1, the least serious of the bilateral trade wars.

In March 2018, in Kigali, Rwanda, 44 African countries signed a framework agreement providing for the creation of a free trade area covering the entire African continent; in July the same year they were joined by five additional countries. By late April 2019, 52 countries had signed the agreement, among which 22 had deposited their instrument of ratification with the Chairperson of the African Union Commission (AUC). Therefore, the agreement entered into force on May 30, 2019. ${ }^{17}$

We propose here a non-detailed assessment of this free trade area. We only account for the consequences of eliminating all tariffs on trade in goods between African countries. We do not go into the potential details of the agreement, such as excluded products, sensitive products, rules of origin, or potential most favored nation clauses in bilateral agreements of some members with non-African countries. Therefore, the modeling exercise here should be considered as indicative. This scenario is entitled S4-AfCFTA.

As and show, the establishment of a free trade area in Africa amplifies the gains that these countries can make from a bilateral trade war: GDP at the continental level increases by 0.03 percent instead of by 0.01 percent, and the real income of the representative consumer increases by US $\$ 3.7$ billion instead of by US $\$ 0.4$ billion. Africa's total exports increase by 3.1 percent in this scenario instead of by 0.1 percent in S1-TW1.

The right-hand side of Table 5.5 shows the variations in bilateral merchandise trade flows between regions in scenario S4-AfCFTA. This scenario implies a very significant increase in trade within Africa (+34.8 percent), including relatively strong growth in the exports of ECOWAS countries and trade in agricultural and agri-food products.

Our results are in accordance with previous studies, particularly Devarajan et al. (2018). Studying the effects of the US-China trade war, Devarajan et al. (2018) consider four possible responses by developing countries: (1) join the trade war; (2) do nothing; (3) pursue regional trade agreements (RTAs) with all regions outside the United States; and (4) option (3) and unilaterally liberalize tariffs on imports from the United States. The results show that joining the trade war is the worst option for developing countries ${ }^{18}$ while forming RTAs with non-US regions and liberalizing tariffs on US imports is the best. ${ }^{19}$ Regional integration in developing countries offsets the negative effects of the trade war even in the absence of removal of tariffs on US imports (scenario 3).

\footnotetext{
17 - The agreement was set to enter into force 30 days after the 22nd country has deposited its instrument of ratification. This happened on April 29, 2019. 18 - African exports decline up to -0.6 percent and GDP falls up to -0.2 percent.

19 - Exports increase up to 2.5 percent and GDP increases up to 1.3 percent.
} 


\section{Conclusions}

While the late 2000s were characterized by emerging non-cooperative trade policies on the export side to protect domestic consumers in the wake of the food price spikes (Bouët and Laborde 2012), the 2016-2019 years have been marked by rising tensions on the import side to protect domestic industries. The bilateral trade war between the United States and China, triggered by the United States, constitutes one of the best illustrations of this new wave of protectionism. A popular proverb in Africa states that when elephants fight, the grass suffers: similarly, there are rising concerns about the extent to which this trade war between the two major players in the world economy could affect Africa. These concerns are legitimate given the strong trade linkages between Africa and China in particular.

Many experts and analysts expect the trade conflict between the United States and China to have negative impacts on Africa. These observers consider that, as China is Africa's most important trading partner, lower exports and lower growth in China would imply a reduction in Chinese imports (mainly commodities), and would lower prices for Africa's exports. We come to a more nuanced conclusion: Africa will register a net gain or a net loss in exports to these large countries depending on the intensity of the trade war. African countries can take advantage of the new opportunity offered to them to increase their exports in both the United States and China under the first scenario, which depicts the changes in tariffs from January 2018 until April 2019. In this case, the trade diversion between the United States and China could be of benefit to Africa in offsetting the negative spillover effects of lower growth, especially in China. Under the second scenario, which includes tariff changes in China and the United States after April 2019, total African exports to China fall owing to this negative spillover effect.

Developing countries outside Africa (mainly Asia) are likely to be the main beneficiaries of the new opportunities in the United States and Chinese markets. The gains for Africa could be amplified if the continent adopts a proactive strategy, with deeper regional integration such as the upcoming African continental free trade area. It is, nonetheless, worth noting that this trade turmoil has other consequences for Africa that are not well captured by this work. For example, it has increased uncertainty in the business climate and diminished investors' confidence, causing the depreciation of local currencies and falls in stock markets (Devermont and Chiang 2019). ${ }^{20}$

Furthermore, if the trading system of the whole world were to become more protectionist, these new opportunities for African countries in the United States and China would cease to be relevant. Indeed, in the case of a multilateral trade war, African exports would fall significantly, with SACU being the most affected region, although intra-continental trade would increase. Deeper integration in Africa while the world becomes more protectionist would be particularly important as, in addition to the trade dispute between China and the United States, there is a clear challenge to multilateralism from the new protectionist US policy. For example, African countries would have to contend with looming threats to the African Growth and Opportunity Act (AGOA). An illustration of this is the US-Rwanda dispute over second-hand clothes. In response to an increase in Rwanda import duties from US $\$ 0.25$ to US $\$ 2.5$ per $\mathrm{kg}$ of secondhand clothes to protect its domestic production, in March 2018, the United States suspended the duty-free access to its market for Rwanda's textile products under AGOA. It is worth noting that the same decision on US products was taken by both Tanzania and Uganda, and if these two countries have not been "punished" yet, this possibility cannot be disregarded in the future.

20 - In South Africa, for instance. 
The United States is also trying to move toward less asymmetrical and non-reciprocal trade deals with Africa and envisages proposing new trade deals with African countries such as South Africa or Kenya, with potential retaliatory measures in case the partner turns the offer down. The main risk here for the United States is to appear relatively unconcerned about Africa's long-term development, undermining the country's reputation and pushing China to deepen its relationships with Africa. Chinese authorities are reinforcing this perception of US actions by employing anti-American rhetoric in their dialogue with African leaders. Chinese authorities are disseminating the message that they alone are interested in developing long-term "winwin" partnerships with Africa, while the United States is focused on its own interests and easy wins. Countries like South Africa and Djibouti ${ }^{21}$ are already receptive to this discourse and could be joined by many others if the United States does not rethink its strategy toward Africa.

\section{References}

ACET (African Center for Economic Transformation). 2014. "The Soybean Agri-Processing Opportunity in Africa." Final Report. Accra: ACET.

AfDB (African Development Bank). 2019. "African Economic Outlook 2019." Abidjan: AfDB.

Aguiar, A., B. Narayanan, and R. McDougall. 2016. "An Overview of the GTAP 9 Data Base." Journal of Global Economic Analysis 1 (1): 181-208.

Amiti, M., S. J. Redding, and D. Weinstein. 2019. The Impact of the 2018 Trade War on US Prices and Welfare. CEPR Discussion Paper DP13564, CEPR, Washington D.C.

Armington, P. S. 1969. A Theory of Demand for Products Distinguished by Place of Production. IMF Staff Papers, 16, pp. 159-178, IMF, Washington D.C.

Bouët, A., and D. Laborde. 2012. "Food Crisis and Export Taxation: The Cost of Non-cooperative Trade Policies." Review of World Economics (Weltwirtschaftliches Archiv) 48 (1): 209-233.

---. 2018. "U.S. Trade Wars in the 21st Century with Emerging Countries: Make America and its Partners Lose Again." The World Economy 41 (9): 2276-2319.

Bouët, A., D. Laborde, D, and F. Traoré. 2018. "The European Union-West Africa Economic Partnership Agreement: Small Impact and New Questions." The Journal of International Trade and Economic Development 27 (1): 25-53.

Bown, C. 2019. The US-China Trade Conflict After 40 Years of Special Protection. PIIE Working Paper 19-7, the Peterson Institute for International Economics, Washington D.C.

Caliendo, L., R. C. Feenstra, J. Romalis, and A. Taylor. 2017. "Tariff Reductions, Entry, and Welfare: Theory and Evidence for the Last Two Decades." NBER Working Paper 21768, National Bureau of Economic Research, Cambridge, MA.

Devarajan, S., D. S. Go, C. Lakatos, S. Robinson, and K. E. Thierfelder. 2018. Traders' Dilemma: Developing Countries' Response to Trade Disputes. Policy Research Working Paper Series 8640, World Bank, Washington, DC.

21 - See the interview of the President of Djibouti: JeuneAfrique.com, April 4, 2017, https://www.jeuneafrique.com/mag/421096/politique/ismail-omarguelleh-personne-dautre-chinois-noffre-partenariat-a-long-terme-a-djibouti/. 
Devermont, J., and C. Chiang. 2019. "Innocent Bystanders. Why the U.S.-China Trade War Hurts African Economies," CSIS Briefs, April, CSIS, Washington, DC.

Fajgelbaum, P. D., P. K. Goldberg, P. J. Kennedy, and A. K. Khandelwal. 2019. The Return to Protectionism, Working Paper 25638. National Bureau of Economic Research, Cambridge.

Freund, C., M. J. Ferrantino, M. Maliszewska, and M. Ruta. 2018. Impacts on Global Trade and Income of Current Trade Disputes. MTI Practice Note, Number 2. Washington, DC: World Bank.

IMF (International Monetary Fund). 2016. Spillovers from China: Financial Channels. Spillover Notes 5. Washington, DC: IMF.

---. 2018. "Regional Economic Outlook: Domestic Revenue Mobilization and Private Investment", Washington, DC: IMF.

---. 2019a. World economic outlook database. April 2019 Edition. https://www.imf.org/ external/pubs/ft/weo/2019/01/weodata/index.aspx.

---.2019b. World Economic Outlook. Growth Slowdown, Precarious Recovery. World Economic and Financial Surveys. Washington, DC: IMF.

---. 2019c. Regional Economic Outlook. Sub-Saharan Africa: Recovery Amid Elevated Uncertainty. World Economic and Financial Surveys. Washington, DC: IMF.

Johnson, H. G. 1953. "Optimum Tariffs and Retaliation." Review of Economic Studies 21 (2): 142-153.

Kohnert, D. 2018. Trump's Tariff's Impact on Africa and the Ambiguous Role of African Agency. MPRA Paper No. 87764, MPRA, Munich.

Laborde, D. and C. Smaller. 2018. Could a U.S.-China trade war lead to a new wave of land grabs? http://www.ifpri.org/blog/could-us---china-trade-war-lead-new-wave-land-grabs.

World Bank. 2019. Global Economic Prospects: Heightened Tension, Subdued Investment. Washington DC: World Bank. 


\section{Appendix: Geographic and Sector Disaggregation}

Table A5.1 Geographic disaggregation

\begin{tabular}{|c|c|}
\hline Region code & GTAP regions \\
\hline Oceania & AUS (Australia), NZL (New Zealand), XOC (Rest of Oceania) \\
\hline $\mathrm{CHN}$ & CHN (China), HKG (Hong Kong) \\
\hline Easia & JPN (Japan), KOR (Korea Republic of) \\
\hline SEAsia & $\begin{array}{l}\text { TWN (Taiwan), XEA (Rest of East Asia), KHM (Cambodia), IDN (Indonesia), LAO (Lao } \\
\text { People's Democratic Republic), MYS (Malaysia), PHL (Philippines), SGP (Singapore), } \\
\text { THA (Thailand), VNM (Viet Nam), XSE (Rest of Southern Asia) }\end{array}$ \\
\hline Sasia & $\begin{array}{l}\text { BGD (Bangladesh), IND (India), PAK (Pakistan), LKA (Sri Lanka), NPL (Nepal), XSA } \\
\text { (Rest of South Asia) }\end{array}$ \\
\hline xNAFTA & CAN (Canada), MEX (Mexico), XNA (Rest of North America) \\
\hline USA & USA (United States of America) \\
\hline LAC & $\begin{array}{l}\text { ARG (Argentina), BOL (Bolivia), BRA (Brazil), CHL (Chile), COL (Colombia), ECU } \\
\text { (Ecuador), PRY (Paraguay), PER (Peru), URY (Uruguay), VEN (Venezuela), XSM (Rest } \\
\text { of South America) }\end{array}$ \\
\hline CAM & $\begin{array}{l}\text { CRI (Costa Rica), GTM (Guatemala), NIC (Nicaragua), PAN (Panama), SLV (EI Salva- } \\
\text { dor), HND (Honduras), XCA (Rest of Central America), DOM (Dominican Republic), } \\
\text { JAM (Jamaica), PRI (Puerto Rico), TTO (Trinidad \& Tobago), XCB (Caribbean) }\end{array}$ \\
\hline EFTA & $\begin{array}{l}\text { AUT (Austria), BEL (Belgium), CYP (Cyprus), CZE (Czech Republic), DNK (Denmark), } \\
\text { EST (Estonia), FIN (Finland), FRA (France), DEU (Germany), GRC (Greece), HUN } \\
\text { (Hungary), IRL (Ireland), ITA (Italy), LVA (Latvia), LTU (Lithuania), LUX (Luxembourg), } \\
\text { MLT (Malta), NLD (Netherlands), POL (Poland), PRT (Portugal), SVK (Slovakia), SVN } \\
\text { (Slovenia), ESP (Spain), SWE (Sweden), GBR (United Kingdom), CHE (Switzerland), } \\
\text { NOR (Norway), XEF (Rest of EFTA), BGR (Bulgaria), HRV (Croatia), ROU (Romania), } \\
\text { XTW (Rest of the world) }\end{array}$ \\
\hline $\mathrm{CIS}$ & $\begin{array}{l}\text { ALB (Albania), BLR (Bulgaria), RUS (Russia), UKR (Ukraine), XEE (Rest of Eastern } \\
\text { Europe), XER (Rest of Europe), KAZ (Kazakhstan), KGZ (Kyrgyzstan), MNG } \\
\text { (Mongolia), XSU (Rest of Former Soviet Union), ARM (Armenia), AZE (Azerbaijan), } \\
\text { GEO (Georgia) }\end{array}$ \\
\hline Gulf & $\begin{array}{l}\text { IRN (Iran), TUR (Turkey), ISR (Israel), JOR (Jordan), ARE (United Arab Emirates), BHR } \\
\text { (Bahrain), KWT (Kuwait), OMN (Oman), QAT (Qatar), SAU (Saudi Arabia), XWS (Rest } \\
\text { of Western Asia) }\end{array}$ \\
\hline XUMACOM & EGY (Egypt), TUN (Tunisia) \\
\hline xUMA & MAR (Morocco), XNF (Rest of North Africa) \\
\hline ECOWAS & $\begin{array}{l}\text { NGA (Nigeria), SEN (Senegal), BEN (Benin), BFA (Burkina Faso), CIV (Côte } \\
\text { d'Ivoire), GHA (Ghana), GIN (Guinea), TGO (Togo), XWF (Rest of Western Africa) }\end{array}$ \\
\hline ECCAS & CMR (Cameroon), XCF (Central Africa), XAC (South Central Africa) \\
\hline xCOMESA & ETH (Ethiopia), KEN (Kenya), RWA (Rwanda), UGA (Uganda) \\
\hline xSADCOM & $\begin{array}{l}\text { MDG (Madagascar), MWI (Malawi), MUS (Mauritius), ZMB (Zambia), ZWE } \\
\text { (Zimbabwe), XEC (Rest of Eastern Africa) }\end{array}$ \\
\hline xSADC & MOZ (Mozambique) \\
\hline TZA & TZA (Tanzania) \\
\hline SACU & $\begin{array}{l}\text { BWA (Botswana), ZAF (South Africa), NAM (Namibia), XSC (Rest of South African } \\
\text { Customs Union) }\end{array}$ \\
\hline
\end{tabular}

Source: GTAP10 database and authors. 
Table A5.2 Sectoral disaggregation

\begin{tabular}{|c|c|c|c|c|c|}
\hline Sector Code & GTAP Sectors & Sector Code & GTAP Sectors & Sector Code & GTAP Sectors \\
\hline Rice & PDR, PCR & Wool & WOL & $\begin{array}{l}\text { Metals and } \\
\text { metal products }\end{array}$ & I_S, NFM, FMP \\
\hline Wheat & WHT & Forestry & FRS & $\begin{array}{l}\text { Transportation } \\
\text { equipment }\end{array}$ & MVH, OTN \\
\hline Corn & GRO & Fish & FSH & $\begin{array}{l}\text { Other manu- } \\
\text { factured goods }\end{array}$ & ELE, OMF \\
\hline $\begin{array}{l}\text { Vegetables and } \\
\text { fruits }\end{array}$ & V_F & Energy Primary & $\begin{array}{l}\text { COA, OIL, } \\
\text { GAS }\end{array}$ & Capital goods & OME \\
\hline Oil seeds & OSD & Minerals & OMN, NMM & Utilities & ELY, GDT, WTR \\
\hline Sugar & C_B, SGR & Vegetable oils & VOL & Construction & CNS \\
\hline Fibers & PFB & Processed food & OFD, B_T & Trade & TRD \\
\hline Other crops & OCR & Textiles & $\begin{array}{l}\text { TEX, WAP, } \\
\text { LEA }\end{array}$ & Transport & OTP, WTP, ATP \\
\hline Red meat & CTL, CMT & $\begin{array}{l}\text { Paper, lumber, } \\
\text { and paper pro- } \\
\text { ducts }\end{array}$ & LUM, PPP & Other services & $\begin{array}{l}\text { CMN, OFI, ISR, } \\
\text { OBS, ROS, } \\
\text { OSG, DWE }\end{array}$ \\
\hline White meat & OAP, OMT & $\begin{array}{l}\text { Coke and petro- } \\
\text { leum products }\end{array}$ & P_C & & \\
\hline Dairy products & RMK, MIL & $\begin{array}{l}\text { Chemical and } \\
\text { rubber products }\end{array}$ & CRP & & \\
\hline
\end{tabular}

Source: GTAP10 database and authors. 